\title{
PENINGKATAN KETERAMPILAN MEMBACA CEPAT DENGAN MEDIA TEKS BERGERAK SISWA KELAS IX-1 SMP HKBP SEI MATI MEDAN
}

\author{
oleh \\ Esra Perangin-angin ${ }^{1}$ (esraperanginangin@unprimdn.c.id) \\ Sri Dinanta Beru Ginting ${ }^{1}$ (sridinanta ginting@pnl.ac.id) \\ Lorenza Delfi Ruth Purba ${ }^{3}$ (purbalorenza@gmail.com) \\ Prodi Pendidikan Bahasa dan Sastra Indonesia \\ Fakultas Keguruan dan Ilmu Pendidikan \\ Universitas Prima Indonesia
}

\begin{abstract}
ABSTRAK- Penelitian ini dilatar belakangi oleh kurang efektifnya pembelajaran membaca cepat yang disebabkan oleh rendahnya minat baca siswa, kecepatan membaca siswa masih di bawah standar kurikulum, pemahaman membaca siswa yang rendah, dan kurang bervariasinya media. Jenis penelitian ini adalah penelitian tindakan kelas (PTK), teknik pengumpulan data dalam penelitian ini adalah teknik kuantitatif untuk menilai tes yang berupa pemahaman isi membaca cepat dan teknik kualitatif yang merupakan hasil observasi, wawancara dan dokumentasi foto. Penelitian ini dilaksanakan dalam dua siklus, masing-masing siklus memiliki empat tahap, yaitu tahap perencanaan, tahap pelaksanaan (tindakan), tahap pengamatan (observasi) dan tahap refleksi. Hasil penelitian menunjukkan adanya peningkatan keterampilan membaca cepat dengan media teks bergerak siswa kelas IX-1 SMP HKBP Sei Mati Medan. Pada siklus I rerata kecepatan membaca siswa adalah $213 \mathrm{kpm}$, rerata pemahaman ide pokok adalah 64, pemahaman simpulan bacaan adalah 61, kecepatan efektif membaca siswa adalah 136 kpm dengan kategori lambatdan presentase ketuntasan siswa adalah $31 \%$.
\end{abstract}

Kata kunci: membaca cepat, media teks bergerak

\section{A. Pendahuluan}

Keterampilan membaca peserta didik yang masih rendah khususnya keterampilan membaca cepat yang tidak luput dari kurangnya konsentrasi siswa saat membaca serta kemampuan siswa dalam menuangkan ide dan kurangnya inovasi yang diberikan guru dalam menciptakan media pembelajaran yang menarik, sehingga siswa tampak kurang berminat dan tertarik terhadap kegiatan membaca cepat.

Dalam pembelajaran membaca cepat peranan seorang pengajar harus mampu memilih media mengajar yang tepat untuk diterapkan. Media tersebut diharapkan mampu mengendalikan cara berfikir peserta didik dalam pembelajaran membaca cepat sehingga tujuan pembelajaran dapat tercapai dengan baik. Membaca cepat menurut Nurhadi (2005) "Speed reading adalah jenis membaca yang mengutamakan kecepatan untuk mengelola secara cepat proses penerimaan informasi dengan tidak meninggalkan pemahaman terhadap aspek bacaan.

Materi pembelajaran membaca cepat didukung dengan media pembelajaran yang tepat, kompetensi guru, sarana dan prasarana, serta minat siswa. Media pembelajaran yang diterapkan pada proses pembelajaran membaca cepat yaitu media teks bergerak. Media pembelajaran teks 
bergerak yang dimaksud adalah teks bergerak yang merupakan hasil Costum Animation dari PowerPoint 2007. Costum Animation ini dapat menghasilkan efek gerakan teks yang bergerak dari bawah ke atas. Selain itu, media pembelajaran teks bergerak memiliki tampilan yang menarik dan dapat meningkatkan konsentrasi siswa, sehingga diharapkan menjadi media yang efektif dibandingkan dengan pembelajaran membaca cepat sebelumnya byang hanya menggunakan teks bacaan biasa. Oleh karena itu, perlu dilakukan penelitian mengenai penggunaan media pembelajaran teks bergerak pada materi pembelajaran membaca cepat mata pelajaran Bahasa Indonesia dalam rangka membantu meningkatkan keterampilan membaca cepat.

\section{B. METODE PENELITIAN}

Metode Penelitian yang digunakan adalah penelitian tindakan kelas. (Arikunto, 2006: 91),"PTK adalah sebuah penelitian yang dilakukan dengan jalan pencermatan terhadap kegiatan belajar mengajar berupa sebuah tindakan, yang sengaja dimunculkan dan terjadi dalam sebuah kelas secara bersama."Subjek penelitian ini adalah siswa kelas IX-1 SMP HKBP Sei Mati, dengan jumlah siswa 35 orang.

Penentuan subjek penelitian sastra Indonesia. Selain itu, jumlah siswa yang lebih sedikit dibandingkan dengan kelas IX yang lain, yaitu 30 siswa, diharapkan dapat mempermudah pengamatan pada saat penelitian. Sementara itu, objek penelitian dalam penelitian tindakan kelas ini adalah keterampilan membaca cepat siswa kelas IX-1 SMP HKBP Sei Mati.

Untuk menentukan presentase penguasaan kemampuan membaca cepat peserta didik dan menghitung nilai rata- rata dengan menggunakan rumus:

$$
\mathrm{X}=\frac{\sum x}{\sum n} \quad \text { Keterangan : }
$$

(Sudjana, 2016: 69)

$$
\mathrm{X}=\text { Nilairata-rata }
$$

$\sum x=$ Jumlah seluruh nilai siswa

$\sum n=$ Jumlah siswa

Selanjutnya di persentasekan dengan

rumus:

Nilai $\frac{\text { Skoryangdiperolehsiswa }}{\text { Skormaksimal }} \times 100$

Kriteria yang digunakan adalah:

Nilai $<75=$ siswa tidak tuntas dalam

belajar

Nilai $\geq 75=$ siswa tuntas dalam belajar

\section{Indikator Keberhasilan}

Indikator keberhasilan dideskripsikan dari kriteria siswa dalam membaca dengan Media Teks Bergerak. Keberhasilan produk ini diperoleh jika nilai rata-rata subjek penelitian meningkat, adapun standar minimal yang ditentukan adalah $70 \%$ dari jumlah siswa yang mengikuti proses belajar mengajar telah mencapai taraf keberhasilan minimal. Penelitian ini dikatakan berhasil apabila nilai rata-rata siswa mencapai minimal 75 sesuai dengan KKM pelajaran Bahasa Indonesia.

\section{HASIL DAN PEMBAHASAN}

\section{Siklus I}

Tahapan pembelajaran siklus I merupakan tindakan awal untuk memperbaiki permasalahan yang terdapat di kelas yaitu rendahnya keterampilan membaca cepat kelas IX-1 SMP HKBP Sei Mati Medan. Penelitian pada siklus I dilaksanakan 2 x pertemuan tanggal 4 April dan 6 April 2018 ( 2 x 40 menit). 
Adapun kegiatan yang dilaksanakan pada siklus I meliputi kegiatan perencanaan tindakan, pelaksanaan tindakan, pengamatan atau observasi, dan refleksi. Pada tahap perencanaan tindakan peneliti bersama guru kolabolator melakukan diskusi dan berkoordinasi untuk merencanakan tindakan yang akan dilakukan selanjutnya. Perencanaan penelitian dilakukan dengan tujuan untuk meningkatkan keterampilan membaca cepat siswa, baik dari segi proses maupun dari segi hasil. Pelaksanaan penelitian tindakan kelas menggunakan media pembelajaran teks bergerak yang diharapkan dapat meningkatkan keterampilan membaca cepat siswa kelas IX-1 SMP HKBP Sei Mati yang dilaksanakan $2 \mathrm{x}$ pertemuan, pada pertemuan pertama peneliti mengenalkan serta siswa media pembelajaran teks bergerak guna melatih siswa untuk membaca cepat. Dan pada pertemuan kedua peneliti menampilkan media teks bergerak untuk mengukur keterampilan membaca cepat siswa.

Hasil tes pada penelitian siklus I sebagai berikut.

Tabel 1 Hasil Tes Kecepatan Efektif

Membaca siswa.

\begin{tabular}{|c|c|c|c|c|}
\hline $\begin{array}{l}\mathbf{N} \\
\mathbf{O}\end{array}$ & $\begin{array}{c}\text { KATEG } \\
\text { ORI }\end{array}$ & $\begin{array}{c}\text { KECEPAT } \\
\text { AN } \\
\text { MEMBAC } \\
\text { A (KPM) }\end{array}$ & $\begin{array}{c}\text { FRE } \\
\text { KUE } \\
\text { NSI }\end{array}$ & $\begin{array}{c}\text { BOBO } \\
\text { T } \\
\text { SKOR }\end{array}$ \\
\hline 1 & $\begin{array}{l}\text { SANGAT } \\
\text { CEPAT }\end{array}$ & $>215$ & 0 & 0 \\
\hline 2 & CEPAT & 188-213 & 11 & 2151 \\
\hline 3 & SEDANG & $140-185$ & 2 & 326 \\
\hline 4 & $\begin{array}{l}\text { LAMBA } \\
T\end{array}$ & $25-138$ & 22 & 2286 \\
\hline \multirow[t]{3}{*}{5} & $\begin{array}{l}\text { SANGAT } \\
\text { LAMBA } \\
T\end{array}$ & $<25$ & 0 & 0 \\
\hline & & JUMLAH & 35 & 4667 \\
\hline & & $\begin{array}{l}\text { RERATA } \\
\text { KLASIKA } \\
\text { L }\end{array}$ & $\begin{array}{l}\frac{4763}{35} \\
=136 \\
.08= \\
136\end{array}$ & $\begin{array}{l}\text { KATE } \\
\text { GORI: } \\
\text { LAMB } \\
\text { AT }\end{array}$ \\
\hline
\end{tabular}

Tabel 1 menunjukkan bahwa KEM siswa kelas IX-1 secara klasikal termasuk dalam kategori lambat, yaitu $136 \mathrm{kpm}$.Belum ada siswa yang termasuk dalam kategori sangat cepat dengan KEM >215.Siswa yang termasuk dalam kategori cepat sebanyak 11 orang atau 31\% dengan KEM 188-213 $\mathrm{kpm}$.Siswa yang termasuk dalam kategori sedang ada 2 orang atau 6\% dengan KEM 140-185 kpm. Siswa yang termasuk dalam kategori lambat sebanyak 22 orang atau $63 \%$ dengan KEM 25-138 kpm. Dalam tes KEM siklus I ini tidak terdapat siswa yang termasuk dalam kategori sangat lambat.Meskipun masih ada siswa yang termasuk dalam kategori lambat.

\section{Siklus II}

Pelaksanaan penelitian tindakan kelas siklus II menggunakan media pembelajaran teks bergerak yang diharapkan dapat meningkatkan keterampilan membaca cepat siswa kelas IX-1 SMP HKBP Sei Mati. Pelaksanaan tindakan dilakukan sebanyak (2 x 40 menit) pada tahapan ini sedikit berbeda dengan siklus I, peneliti langsung menggunakan media teks bergerak untuk mengukur kecepatan membaca siswa.

Hasil tes penelitian siklus II sebagai berikut. 
TABEL 2 Hasil Tes Kecepatan

Efektif Membaca Siswa.

\begin{tabular}{|c|c|c|c|c|}
\hline O & $\begin{array}{c}\text { KAT } \\
\text { EGO } \\
\text { RI }\end{array}$ & $\begin{array}{c}\text { KECEP } \\
\text { ATAN } \\
\text { MEMB } \\
\text { ACA } \\
\text { (KPM) }\end{array}$ & $\begin{array}{l}\text { FR } \\
\text { EK } \\
\text { UE } \\
\text { NSI }\end{array}$ & $\begin{array}{c}\text { BOBO } \\
\text { T } \\
\text { SKOR }\end{array}$ \\
\hline 1 & $\begin{array}{l}\text { SAN } \\
\text { GAT } \\
\text { CEPA } \\
\text { T }\end{array}$ & $>215$ & 6 & 1359 \\
\hline 2 & $\begin{array}{l}\text { CEPA } \\
\mathrm{T} \\
\end{array}$ & 188-213 & 19 & 3680 \\
\hline 3 & $\begin{array}{l}\text { SEDA } \\
\text { NG }\end{array}$ & $140-185$ & 6 & 1004 \\
\hline 4 & $\begin{array}{l}\text { LAM } \\
\text { BAT }\end{array}$ & 25-138 & 4 & 449 \\
\hline 5 & $\begin{array}{l}\text { SAN } \\
\text { GAT } \\
\text { LAM } \\
\text { BAT }\end{array}$ & $<25$ & 0 & 0 \\
\hline & & $\begin{array}{l}\text { JUMLA } \\
\text { H }\end{array}$ & 35 & 6867 \\
\hline & & $\begin{array}{l}\text { RERAT } \\
\text { A } \\
\text { KLASI } \\
\text { KAL }\end{array}$ & $\begin{array}{l}\frac{649}{2} \\
\frac{255}{35} \\
= \\
185, \\
48 \\
= \\
185\end{array}$ & $\begin{array}{l}\text { KATE } \\
\text { GORI: } \\
\text { Sedang }\end{array}$ \\
\hline
\end{tabular}

Tabel 2 menunjukkan bahwa KEM (Kecepatan Efektif Membaca) siswa kelas IX-1 secara klasikal termasuk dalam kategori sedang, yaitu $185 \mathrm{kpm}$. Siswa yang mencapai kategori sangat cepat dengan KEM (Kecepatan Efektif Membaca) lebih dari $215 \mathrm{kpm}$ sebanyak 6 orang atau $17 \%$. Siswa yang termasuk dalam kategori cepat sebanyak 19 orang atau 54\% dengan KEM (Kecepatan Efektif Membaca) 188-213 kpm. Siswa yang termasuk dalam kategori sedang sebanyak 6 orang atau 17\% dengan KEM (Kecepatan Efektif Membaca) 140-185 kpm. Siswa yang termasuk dalam kategori lambat sebanyak 4 orang atau 12\% dengan KEM (Kecepatan Efektif Membaca) 25-138 kpm. Dalam hasil tes kecepatan efektif membaca siklus II ini tidak ada terdapat yang termasuk dalam kategori sangat lambat.

Hasil tes KEM (Kecepatan Efektif Membaca) pada siklus II mengalami peningkatan sebesar 49 jika dibandingan dengan tes KEM (Kecepatan Efektif Membaca) pada siklus I yaitu 136. Dapat disimpulkan bahwa penelitian pada siklus II mengalami peningkatan yang sudah sesuai dengan kategori keberhasilan.

Pembelajaran membaca cepat merupakan kompetensi dasar yang tertera dalam silabus pelajaran bahasa Indonesia khususnya Siswa Menengah Pertama (SMP), maka dalam proses pembelajaran perlu diperhatikan media atau model yang tepat dalam menyampaikan pembelajaran membaca cepat, agar pembelajaran membaca cepat tidak membosankan bagi siswa. Maka guru bidang studi harus mampu memilih dan menerapkan media atau model yang tepat untuk meningkatkan keterampilan siswa dalam membaca cepat, untuk itu peneliti menggunakan media pembelajaran teks bergerak.

Media pembelajaran teks bergerak yang dimaksud adalah teks bergerak yang merupakan hasil Costum Animation dari Power Point 2007. Costum Animation ini dapat menghasilkan efek gerakan teks yang bergerak dari bawah ke atas.Media pembelajaran teks bergerak tersebut dapat dijadikan sebagai media pembelajaran membaca cepat karena kecepatan bergeraknya teks bisa diatur sesuai dengan kebutuhan, yaitu dengan ukuran KPM (Kata Per menit). Selain itu media pembelajaran teks bergerak memiliki tampilan yang menarik dan dapat meningkatkan konsentrasi siswa, sehingga diharapkan 
menjadi media yang efektif dibandingkan dengan pembelajaran membaca cepat sebelumnya yang hanya menggunakan teks bacaan biasa.

Pelaksanaan pembelajaran membaca cepat dengan menggunakan media teks bergerak dilakukan dalam dua siklus dan tiap dilaksanakan dalam dua kali pertemuan kegiatan pembelajaran difokuskan pada kecepatan efektif membaca siswa dengan media teks bergerak dan perubahan perilaku siswa dari perilaku negatif ke perilaku positif. Adapun perubahan perilaku tersebut diuraikan sebagai berikut.

Pada siklus I, aspek 1 siswa yang memperhatikan dan merespon pelajaran dengan antusias dan sungguh-sungguh dengan cara bertanya, menanggapi, dan menjawab pertanyaan sebanyak 30 orang saja atau $85,71 \%$. Siswa yang tidak memperhatikan penjelasan guru dan melakukan aktifitas yang tidak perlu seperti berbicara sendiri, kepala disandarkan di meja, dan mondar- mandir sebanyak 5 orang atau $14,28 \%$. dan pada siklus II, siswa yang memperhatikan dan merespon pelajaran dengan antusias dan sungguh-sungguh dengan cara bertanya, menanggapi, dan menjawab pertanyaan sebanyak 35 orang saja atau $100 \%$ serta tidak ada siswa yang tidak memperhatikan penjelasan guru dan melakukan aktifitas yang tidak perlu seperti berbicara sendiri, kepala disandarkan di meja, dan mondar-mandir.

Aspek 2 pada siklus I, Pada aspek 2, Siswa yang melakukan kegiatan membaca cepat dengan penuh perhatian dan tidak melakukan hambatan dalam membaca cepat sebanyak 25 orang atau 71,42\% Siswa yang kurang berpartisipasi dan masih melakukan hambatan dalam membaca cepat sebanyak 10 orang atau $28,57 \%$, dan pada siklus II mengalami peningkatan, Siswa yang melakukan kegiatan membaca cepat dengan penuh perhatian dan tidak melakukan hambatan dalam membaca cepat sebanyak 33 orang atau 94\% Siswa yang kurang berpartisipasi dan masih melakukan hambatan dalam membaca cepat sebanyak 2 orang atau $5 \%$.

Aspek 3 pada siklus I, siswa yang serius dalam mengerjakan soal tes yang diberikan guru sebanyak 33 siswa atau 94,28\%. Siswa yang tidak serius dalam mengerjakan soal tes yang diberikan guru sebanyak 2 orang atau 5,71\%. Pada siklus II siswa yang serius dalam mengerjakan soal tes yang diberikan guru sebanyak 35 siswa atau $100 \%$ dan tidak ada siswa yang tidak serius dalam mengerjakan soal tes yang diberikan guru.

Pada aspek 4, siklus I siswa yang aktif bertanya ketika mengalami kesulitan dalam pembelajaran sebanyak 25 orang atau $71,42 \%$. Siswa yang enggan bertanya ketika mengalami kesulitan selama pembelajaran sebanyak 10 orang atau $28,57 \%$ dan di siklus II mengalami perubahan, siswa yang aktif bertanya ketika mengalami kesulitan dalam pembelajaran sebanyak 30 orang atau $86 \%$. Siswa yang enggan bertanya ketika mengalami kesulitan selama pembelajaran sebanyak 5 orang atau $14 \%$. Selain perubahan perilaku, hasil kecepatan membaca siswa juga meningkat mulai dari kecepatan membaca, pemahaman ide pokok, simpulan bacaan dan kecepatan efektif membaca siswa dari siklus I, dimana hasil kecepatan membaca siswa adalah 213 meningkat menjadi 236, hasil 
pemahaman ide pokok siswa adalah 64 meningkat menjadi 79, pemahaman simpulan bacaan siswa adalah 61 menigkat menjadi 76 dan hasil keseluruhan yaitu kecepatan efektif membaca siswa adalah 136 meningkat menjadi 185, dari hasil tersebut ketuntasan siswa yang sesuai dengan kriteria keberhasilan dan KKM pada siklus I adalah $31 \%$ siswa yang mencapai ketuntasan meningkat menjadi $71 \%$ siswa yang mencapai kriteria keberhasilan dan KKM yang sudah ditentukan pada siklus II, untuk itu dapat disimpulkan bahwa kecepatan membaca siswa mengalami peningkatan yang sesuai dengan indikator keberhasilan yaitu $70 \%$ dan yang dicapai siswa adalah $71 \%$ pada siklus II.

Tabel 3 Peningkatan kecepatan

membaca, pemahaman isi dan

kecepatan efektif membaca

\begin{tabular}{|l|l|l|}
\hline \multirow{2}{*}{ Kategori } & \multicolumn{2}{c|}{ Skor rata-rata } \\
\cline { 2 - 3 } & Siklus I & $\begin{array}{l}\text { Siklus } \\
\text { II }\end{array}$ \\
\hline $\begin{array}{l}\text { Kecepatan Efektif } \\
\text { Membaca (KEM) }\end{array}$ & 136 & 185 \\
\hline $\begin{array}{l}\text { Presentasi Ketuntasan } \\
\text { Presentasi Tidak }\end{array}$ & $31 \%$ & $71 \%$ \\
\hline Tuntas & $69 \%$ & $29 \%$ \\
\hline Kategori & Lambat & Sedang \\
\hline
\end{tabular}

\section{DAFTAR PUSTAKA}

Arikunto, Suharsini. 2006. Prosedur Penelitian Suatu Pendekatan Praktik. Jakarta: Rineka Cipta.

Asnawir. 2011. Media Pembelajaran. Jakarta Rineka Cipta

Arsyad,Azar. 2016.Media Pembelajaran, Edisi Revisi. Jakarta: PTR aja granfind Persada.
Fitrianissa, Syarifah (2013) yang berbentuk jurnal dengan judul: "Kemampuan Membaca Cepat Siswa Kelas VII SMP Negeri 1 Pulau Tiga Kecamatan Pulau Tiga Kabupaten Natuna Tahun Ajaran 2012/2013"

Harjasujana, Akhmad Slamet dan Yeti Mulyati. 1996. Membaca 2.Jakarta:

Departemen Pendidikan dan Direktorat Jendral Pendidikan Dasar dan Menengah Bagian Proyek Penataran Guru SLTP Setara D-III Tahun 1996/1997.

Hidayat, Rahmat. 2012. Peningkatan Keterampilan Membaca cepat Wacana Deskripsi dengan Menggunakan Media Teks bergerak.Pada siswa kelas VIII Negeri 2 Pleret

Juanda, Dadan (2016 "Keterampilan Membaca Cepat Dalam Menemukan Gagasan Utama”.

Komolasri, Hilda (2014) yang berjudul "Peningkatan Keterampilan Membaca Cepat Melalui Teknik Skimming Mata Pelajaran Bahasa Indonesia Kelas V SD Al-Zahra Indonesia Pamulang Tahun Ajaran 2013/2014."

Keraf, Gorys. 1981. Eksposisi dan Deskripsi. Flores: Nusa Indah.

Madya, Suwarsih. 2006. Teori dan Praktik Penelitian Tindakan. Bandung: Alfabeta. 
Murdiyani, Puput Devi. 2011. Peningkatan Keterampilan Membaca Cepat Menggunakan Metode Kalimat Media Teks Berjalan (MARQUEE. Pada kelas VIII D SMP Negeri 4 Cepiring Kecamatan Cepiring Kabupaten Kendal.

Nurhadi. 2004. Bagaimana Meningkatkan Kemampuan Membaca. Bandung: Sinar Baru Algesindo.

Nurhadi.2008. Membaca Cepat dan Efektif (Teori dan Latihan). Jakarta: Sinar Dunia Algensindo.

Soedarsosno. 2006. Speed Reading Sistem Membaca Cepat dan Efektif. Jakarta:PT. Gramedia Pustaka Utama.

Somadayo, Samsu. 2011. Strategi dan Teknik Pembelajaran Membaca. Yokyakarta: Graha Ilmu.

Wati, Ega Rima. 2016. Ragam Media Pembelajaran. Kata Pena.

Wiryodijoyo, Suwaryono. 1989. Membaca: Strategi Pengantar dan Tekniknya. Jakarta: Departemen Pendidikan dan Kebudayaan Direktorat Jendral Pendidikan Tinggi Proyek Pengembangan Lembaga Pendidikan Tenaga Kependidikan. 